\title{
PENGARUH DOSIS DAN WAKTU PEMBERIAN KOMPOS TERHADAP PERTUMBUHAN BAYAM
} CABUT Amarathus gangeticus

\section{THE EFFECT OF DOSAGE AND TIME OF GIVING COMPOS ON THE GROWTH OP SPINACH Amarathus gangeticus}

\author{
Ahmad Raksun*, I Wayan Merta, dan I Gde Mertha \\ Program Studi Pendidikan Biologi Universitas mataram, Indonesia \\ *Email: ahmadunram@unram.ac.id
}

Diterima: 6 Maret 2021. Disetujui: 24 Mei 2021. Dipublikasikan: 2 Juni 2021

\begin{abstract}
Abstrak: Penelitian tentang pengaruh dosis dan waktu pemberian kompos terhadap pertumbuhan bayam cabut sudah dilakuakan di Desa Terong tawah pada bulan Juni sampai dengan November 2020. Tujuan penelitian adalah untuk mengetahui: (1) pengaruh dosis kompos terhadap pertumbuhan bayam cabut, (2). pengaruh waktu pemberian kompos terhadap pertumbuhan bayam cabut, (3) pengaruh interaksi antara dosis dan waktu pemberian kompos terhadap pertumbuhan bayam cabut, (4) kadar optimum kompos yang harus diberikan pada lahan pertanian agar bayam cabut dapat tumbuh secara optimal. Dalam penelitian ini digunakan rancangan 2 faktor dengan 3 ulangan. Parameter pertumbuhan yang diukur adalah tinggi batang, jumlah daun, panjang daun dan diameter batang bayam cabut. Hasil analisis data menujukkan bahwa F hitung > F tabel untuk semua parameter yang diukur. Dengan demikian disimpulkan bahwa: (1) perbedaan dosis kompos berpengaruh nyata terhadap tinggi batang, jumlah daun, panjang daun dan diameter batang bayam cabut, (2) perbedaan waktu pemberian kompos berpengaruh nyata terhadap semua parameter pertumbuhan yang diukur, (3) interaksi antara dosis dan waktu pemberian kompos tidak berpengaruh nyata semua parameter pertumbuhan yang diukur, (4) dosis optimum kompos adalah 1,5 kg per $1 \mathrm{~m}^{2}$ lahan pertanian, (5) pemberian kompos 28 hari sebelum tanam memberikan hasil pertumbuhan bayam cabut yang lebih baik dari pada perlakuan lainnya.
\end{abstract}

Kata kunci: dosis kompos, pertumbuhan bayam

Abstract: Research on the effect of dosage and timing of compost on the growth of spinach has been carried out in the village of Terong Tawah, West Lombok Regency, from June to November 2020. This research aimed to find out: (1) the effect of compost dose on the growth of spinach, (2) the effect of compost application time on the growth of spinach, (3) the effect of the interaction between dose and time of compost application on the growth of spinach, (4) the optimum dose of compost that must be given to agricultural land so that spinach can grow optimally. In This research, a 2-factor design with three replications was used. Growth parameters measured were stem height, number of leaves, leaf length, and stem diameter. The results of data analysis show that $\mathrm{F}$ count $>\mathrm{F}$ table for all parameters measured. Therefore, it was concluded that: (1) the difference in compost dose has a significant effect on stem height, the number of leaves, leaf length, and stem diameter, (2) the difference in compost application time has a significant effect on all measured growth parameters, (3) the interaction between the dose and time of compost application has no significant effect on all measured growth parameters, (4) The optimum dose of compost is $1,5 \mathrm{~kg}$ for $1 \mathrm{~m}^{2}$ of agricultural land, (5) giving compost 28 days before planting gives better growth of spinach than other treatments.

Keywords: compost dosage, spinach growth

\section{PENDAHULUAN}

Bayam cabut adalah bayam yang dipanen dengan cara dicabut seluruh bagian tanaman beserta akarnya. Bayam cabut mengandung serat yang tinggi. Selain mengandung serat, bayam cabut mengandung berbagai zat gizi yang lain. Dalam 100 gram bayam cabut terdapat 3,5 gram protein, 6,5 gram karbohidrat. Bayam cabut juga mengandung vitamin A, vitamin B dan vitamin vitamin C. Selanjutnya mineral yang terkandung dalam bayam cabut adalah calsium, fosfor dan besi [1].

Ketersediaan unsur hara pada lahan pertanian merupakan salah satu faktor yang sangat menen terhadap pertumbuhan bayam cabut. Berbagai upaya dapat dilakukan dalam meningkatkan ketersediaan unsur hara pada lahan pertanian, diantaranya adalah dengan pemupukan baik dengan menggunakan pupuk organik maupun pupuk anorganik. Salah satu pupuk organik yang dapat digunakan adalah kompos. Kompos merupakan pupuk organik yang dihasilkan dari proses pengolahan sampah organik. Pupuk organik kompos yang dihasilkan dapat digunakan untuk menigkatkan pertumbuhan dan produksi tanaman. Pemberian pupuk organik pada lahan pertanian sangat penting dalam menjaga kesuburan tanah dan pertumbuhan 
tanaman. Pemberian pupuk organik dapat memperbaiki sifat fisik, kimia dan biologi tanah [2]. Sifat fisik, kimia dan biologi tanah yang baik berpengaruh positif terhadap pertumbuhan dan produksi tanaman.

Pemanfaatan kompos atau pupuk organik pada lahan pertanian berdampak positif terhadap ketersedian hara, pertumbuhan dan produksi tanaman. Hasil penelitian yang dilakukan oleh [3] menunjukkan bahwa pemberian pupuk kompos mampu meningkatkan pertumbuhan dan produksi padi di lahan pasang surut sulfat masam. Perlakuan kompos feses sapi berpengaruh nyata terhadap peningkatan tinggi batang, panjang daun dan berat basah buah terung hijau [4]. Pemberian kompos berpengaruh nyata terhadap tinggi tanaman, umur berbunga, umur panen dan berat buah cabai rawit [5]. Pemberian kompos berpengaruh nyata terhadap tinggi tanaman, panjang daun, lebar daun, diameter batang, waktu muncul bunga jantan dan bunga betina, panjang tongkol dan jumlah biji tanaman jagung manis [6]. Dosis kompos berpengaruh nyata terhadap panjang buah dan berat basah buah cabai rawit. Dosis kompos optimum adalah 1,6 - $2 \mathrm{~kg}$ kompos per $1 \mathrm{~m}^{2}$ lahan pertanian [7].

Berdasarkan uraian di atas maka dilakukan penelitian tentang pengaruh dosis dan waktu pemberian kompos terhadap pertumbuhan bayam cabut. Penelitian ini sudah dilaksanakan di Desa Terong Tawah Kecamatan Labuapi Kabupaten Lombok Barat. Tujuan penelitian ini adalah untuk mengetahui (1) pengaruh dosis kompos terhadap pertumbuhan bayam cabut, (2). pengaruh waktu pemberian kompos terhadap pertumbuhan bayam cabut, (3) pengaruh interaksi antara dosis dan waktu pemberian kompos terhadap pertumbuhan bayam cabut, (4) dosis optimum kompos yang harus diberikan pada lahan pertanian agar bayam cabut tumbuh secara optimal.

\section{METODE}

Kegiatan penelitian ini telah dilaksanakan mulai bulan Juni sampai dengan Oktober 2020 dengan tahapan kegiatan yaitu: (1) pembuatan kompos, (2) pengolahan lahan pertanian, (3) pemberian kompos pada lahan pertanian, (3) penanaman bayam cabut (4) pemeliharaan tanaman, (5) pengukuran paremeter pertumbuhan bayam cabut.

Bahan yang digunakan dalam pembuatan kompos adalah feses sapi, timbangan, karung goni, karung nilon, sekam (kulit padi), kompos yang sudah matang, dedak halus dan air. Selanjutnya alat yang digunakan adalah ember plastik, gentong air, gelas ukur, cangkul, parang, linggis, sekop, artco dorong dan timbangan. Kegiatan berikutnya adalah aplikasi kompos pada lahan pertanian. Bahan-bahan yang digunakan dalam kegiatan ini adalah benih bayam cabut, kompos, insektisida, fungisida dan air.
Selanjutnya alat yang digunakan adalah ember plastik, parang, palu, artco dorong, hand sprayer, cangkul, timbangan, alat tulis menulis, gunting dan mesin pompa air

Dalam penelitian ini digunakan rancangan faktorial yang terdiri atas 2 faktor. Faktor pertama adalah dosis kompos yang terdiri atas 5 level yaitu: $\mathrm{K}_{\mathrm{o}}=$ tampa pemberian kompos (kontrol), $\mathrm{K}_{1}=$ pemberian $0,5 \mathrm{~kg}$ kompos per $1 \mathrm{~m}^{2}$ lahan pertanian, $\mathrm{K}_{2}=$ pemberian $1,0 \mathrm{~kg}$ kompos per $1 \mathrm{~m}^{2}$ lahan pertanian, $\mathrm{K}_{3}=$ pemberian $1,5 \mathrm{~kg}$ kompos per $1 \mathrm{~m}^{2}$ lahan pertanian, $\mathrm{K}_{4}=$ pemberian 2,0 $\mathrm{kg}$ kompos per $1 \mathrm{~m}^{2}$ lahan pertanian. Faktor kedua adalah waktu pemberian kompos yang terdiri atas 4 macam waktu. Pemberian kompos 7 hari sebelum tanam $\left(\mathrm{W}_{1}\right)$, pemberian kompos 14 hari sebelum tanam $\left(\mathrm{W}_{2}\right)$ Pemberian kompos 21 hari sebelum tanam $\left(\mathrm{W}_{3}\right)$ Pemberian kompos 28 hari sebelum tanam $\left(\mathrm{W}_{4}\right)$. Parameter pertumbuhan yang diukur adalah tinggi batang, jumlah daun, panjang daun, lebar daun dan diameter batang, Data hasi pengukuran parameter di atas dianalisis dengan analisis sidik ragam dan uji lanjut dengan Uji Beda Nyata Terkecil [8] [9]

\section{HASIL DAN PEMBAHASAN \\ Tinggi batang}

Penelitian tentang pengaruh dosis dan waktu pemberian kompos terhadap pertumbuhan bayam cabut telah dilaksanakan di Desa Terong Tawah Kecamatan Labuapi Kabupaten Lombok Barat. Parameter pertumbuhan bayam cabut yang diukur meliputi tinggi batang, diameter batang, jumlah daun, panjang helaian daun dan lebar helaian daun bayam cabut.. Data hasil pengukuran tinggi batang bayam cabut akibat perbedaan dosis dan waktu pemberian kompos terdapat pada tabel 1 .

Data pada tabel 1 menunjukan bahwa tinggi batang bayam cabut terendah adalah $20 \mathrm{~cm}$, terdapat pada perlakuan $\mathrm{W}_{1} \mathrm{~K}_{0}$, yaitu pada tanaman tidak diberi perlakuan kompos (kontrol perlakuan). Selanjutnya tanaman bayam cabut dengan tinggi batang tertinggi adalah $26 \mathrm{~cm}$, terdapat pada perlakuan $\mathrm{W}_{4} \mathrm{~K}_{3}$ yaitu bayam cabut yang diberi perlakuan $1,5 \mathrm{~kg}$ kompos yang diberikan 28 hari sebelum tanam. Hasil analisis sidik ragam pengaruh dosis dan waktu pemberian kompos terhadap tinggi batang tanaman bayam cabut disajikan pada tabel 2 .

Hasil analisis sidik ragam nenjukkan bahwa perlakuan kompos berpengaruh nyata terhadap tinggi batang bayam cabut. Waktu pemberian kompos berpengaruh nyata terhadap tinggi batang bayam cabut. Interaksi dosis dan waktu pemberian kompos tidak berpengaruh nyata terhadap tinggi batang bayam cabut. Adanya pengaruh nyata aplikasi kompos terhadap tinggi batang bayam cabut dimungkinkan karena kompos merupakan pupuk organik yang dapat memperbaiki sifat fisika dan kimia tanah. [10] melaporkan bahwa pemberian pupuk organik dapat memperbaiki sifat 
fisika tanah terutama pada bobot isi tanah, porositas dan permeabilitas.

Pemberian pupuk organik kompos kotoran sapi, kotoran ayam, daun gamal dan daun angsana dapat memperbaiki sifat fisik tanah (kelengasan tanah dan porositas tanah) dan sifat kimia tanah ( $\mathrm{pH}$ tanah, C-organik tanah dan Bahan organik tanah [11].

Hasil penelitian ini sejalan dengan hasil penelitian [12] yang menyimpulkan bahwa penggunaan kompos pada lahan pertanian Desa Sukarare berpengaruh nyata terhadap panjang batang kacang panjang. Dosis optimum kompos yang perlu diberikan pada lahan pertanian Desa Sukarara agar kacang panjang dapat tumbuh secara optimal adalah $2,0 \mathrm{~kg}$ kompos untuk $1 \mathrm{~m}^{2}$ .Demikian juga [13] menemukan bahwa Perbedaan dosis kompos berpengaruh nyata terhadap tinggi batang kangkung darat .Perbedaan waktu pemberian kompos berpengaruh nyata terhadap tinggi batang kangkung darat. Dosis optimum kompos yang perlu diberikan pada lahan pertanian Desa Bajur Kecamatan Labuapi agar kangkung darat dapat tumbuh optimal adalh $1,5 \mathrm{~kg}$ per $1 \mathrm{~m}^{2}$ lahan pertanian. Pemberian kompos greenbotane pada bibit kelapa sawit berpengaruh nyata terhadap parameter tinggi tanaman bibit kelapa sawit. Peningkatan dosis perlakuan didiringi dengan peningkatan pertumbuhan bibit di setiap parameter pengamatan. Pemberian pupuk kompos green botane dosis $200 \mathrm{~g} /$ polybag merupakan dosis perlakuan terbaik terhadap seluruh parameter pengamatan [14]. Penggunaan bokashi EM4 memberikan pengaruh terhadap penambahan tinggi tanaman sawi umur 3 dan 4 minggu setelah tanam [15]. Penggunaan pupuk organik berpengaruh nyata terhadap parameter tinggi batang tanaman, diameter batang, indeks luas daun, panjang tongkol dan bobot segar tongkol per hektar tanaman jagung manis [16].

\section{Jumlah Daun}

Jumlah daun bayam cabut bervariasi pada masing-masing unit percobaan. Rerata jumlah daun terendah terdapat pada kontrol perlakuan. Selanjutnya rerata jumlah daun bayam cabut meningkat sejalan dengan meningkatnya dosis kompos yang diberikan. Secara lengap rerata jumlah daun bayam cabut pada umus 22 hari setelah tanam disajikan pada tabel 3 .

Rerata jumlah daun pada tabel 3 menunjukan bahwa rerata jumlah daun bayam cabut terendah adalah 5 helaian daun, terdapat pada perlakuan $\mathrm{W}_{1} \mathrm{~K}_{0}$, yaitu pada tanaman tidak diberi perlakuan kompos (kontrol perlakuan). Adapun tanaman bayam cabut dengan jumlah daun tertinggi adalah 9 helaian daun terdapat pada perlakuan $\mathrm{W}_{4} \mathrm{~K}_{3}$ yaitu bayam cabut yang diberi perlakuan $1,5 \mathrm{~kg}$ kompos 28 hari sebelum tanam. Hasil analisis sidik ragam pengaruh dosis dan waktu pemberian kompos terhadap jumlah daun tanaman bayam cabut disajikan pada tabel 4.

Tabel 1. Rerata tinggi batang bayam cabut akibat perbedaan dosis dan waktu pemberian kompos

\begin{tabular}{cccc}
\hline Perlakuan & Tinggi Batang $(\mathrm{cm})$ & Perlakuan & Tinggi Batang $(\mathrm{cm})$ \\
\hline $\mathrm{W}_{1} \mathrm{~K}_{0}$ & 20 & $\mathrm{~W}_{3} \mathrm{~K}_{0}$ & 22 \\
$\mathrm{~W}_{1} \mathrm{~K}_{1}$ & 21 & $\mathrm{~W}_{3} \mathrm{~K}_{1}$ & 23 \\
$\mathrm{~W}_{1} \mathrm{~K}_{2}$ & 22 & $\mathrm{~W}_{3} \mathrm{~K}_{2}$ & 23 \\
$\mathrm{~W}_{1} \mathrm{~K}_{3}$ & 21 & $\mathrm{~W}_{3} \mathrm{~K}_{3}$ & 24 \\
$\mathrm{~W}_{1} \mathrm{~K}_{4}$ & 20 & $\mathrm{~W}_{3} \mathrm{~K}_{4}$ & 21 \\
$\mathrm{~W}_{2} \mathrm{~K}_{0}$ & 21 & $\mathrm{~W}_{4} \mathrm{~K}_{0}$ & 23 \\
$\mathrm{~W}_{2} \mathrm{~K}_{1}$ & 22 & $\mathrm{~W}_{4} \mathrm{~K}_{1}$ & 23 \\
$\mathrm{~W}_{2} \mathrm{~K}_{2}$ & 23 & $\mathrm{~W}_{4} \mathrm{~K}_{2}$ & 24 \\
$\mathrm{~W}_{2} \mathrm{~K}_{3}$ & 23 & $\mathrm{~W}_{4} \mathrm{~K}_{3}$ & 26 \\
$\mathrm{~W}_{2} \mathrm{~K}_{4}$ & 19 & $\mathrm{~W}_{4} \mathrm{~K}_{4}$ & 23 \\
\hline
\end{tabular}

Tabel 2. Hasil analisis sidik ragam pengaruh dosis dan waktu pemberian kompos terhadap tinggi batang bayam cabut

\begin{tabular}{lrrrrr}
\hline \multicolumn{1}{c}{ Sumber Keragaman } & D B & \multicolumn{1}{c}{ J K } & \multicolumn{1}{c}{ K T } & F. Hitung & F. Tabel $(0,05)$ \\
\hline Dosis Kompos (K) & 4 & 56,9 & 14,23 & 9,48 & 2,62 \\
Waktu Perlakuan Kompos (K) & 3 & 69,73 & 23,24 & 15,48 & 2,85 \\
W X K & 12 & 14,43 & 1,20 & 0,80 & 1,99 \\
Galat & 38 & 57,04 & 1,50 & & \\
\hline
\end{tabular}


Tabel 3. Rerata jumlah daun bayam cabut akibat perbedaan dosis dan waktu pemberian kompos

\begin{tabular}{cccc}
\hline Perlakuan & Jumlah Daun (helai) & Perlakuan & Jumlah Daun (helai) \\
\hline $\mathrm{W}_{1} \mathrm{~K}_{0}$ & 5 & $\mathrm{~W}_{3} \mathrm{~K}_{0}$ & 6 \\
$\mathrm{~W}_{1} \mathrm{~K}_{1}$ & 6 & $\mathrm{~W}_{3} \mathrm{~K}_{1}$ & 7 \\
$\mathrm{~W}_{1} \mathrm{~K}_{2}$ & 6 & $\mathrm{~W}_{3} \mathrm{~K}_{2}$ & 7 \\
$\mathrm{~W}_{1} \mathrm{~K}_{3}$ & 6 & $\mathrm{~W}_{3} \mathrm{~K}_{3}$ & 7 \\
$\mathrm{~W}_{1} \mathrm{~K}_{4}$ & 5 & $\mathrm{~W}_{3} \mathrm{~K}_{4}$ & 6 \\
$\mathrm{~W}_{2} \mathrm{~K}_{0}$ & 5 & $\mathrm{~W}_{4} \mathrm{~K}_{0}$ & 6 \\
$\mathrm{~W}_{2} \mathrm{~K}_{1}$ & 6 & $\mathrm{~W}_{4} \mathrm{~K}_{1}$ & 7 \\
$\mathrm{~W}_{2} \mathrm{~K}_{2}$ & 6 & $\mathrm{~W}_{4} \mathrm{~K}_{2}$ & 7 \\
$\mathrm{~W}_{2} \mathrm{~K}_{3}$ & 7 & $\mathrm{~W}_{4} \mathrm{~K}_{3}$ & 9 \\
$\mathrm{~W}_{2} \mathrm{~K}_{4}$ & 6 & $\mathrm{~W}_{4} \mathrm{~K}_{4}$ & 7 \\
\hline
\end{tabular}

Tabel 4. Hasil analisis sidik ragam pengaruh dosis dan waktu pemberian kompos terhadap jumlah daun bayam cabut

\begin{tabular}{|l|r|r|r|r|r|}
\hline \multicolumn{1}{|c|}{ Sumber Keragaman } & DB & JK & KT & F. Hitung & \multicolumn{1}{c|}{$\begin{array}{c}\text { F. Tabel } \\
(0,05)\end{array}$} \\
\hline Dosis Kompos (K) & 4 & 19,57 & 4,89 & 12,13 & 2,62 \\
\hline Waktu Perlakuan Kompos (K) & 3 & 18,53 & 6,18 & 15,31 & 2,85 \\
\hline W X K & 12 & 3,07 & 0,26 & 0,63 & 1,99 \\
\hline Galat & 38 & 15,33 & 0,40 & & \\
\hline
\end{tabular}

Berdasarkan hasil analisis data pada tabel 4 diketahui bahwa perbedaan dosis kompos berpengaruh signifikan terhadap jumlah daun tanaman bayam cabut. Demikian juga bahwa perbedaan waktu aplikasi kompos berpengaruh nyata terhadap jumlah daun bayam cabut. Interaksi antara dosis dan waktu pemberian kompos tidak berpengaruh nyata terhadap jumlah helaian daun bayam cabut

Hasil penelitian ini sejalan dengan hasil penelitian [18] yang menyimpulkan bahwa perlakuan kompos berpengaruh nyata terhadap peningkatan jumlah daun tanaman cabai merah. perlakuan pupuk kompos 20\% memberikan pengaruh yang sangat baik pada setiap parameter pertumbuhan dan pada hasil produktivitas cabai merah. [19] menemukan bahwa pemberian pupuk organik bokashi berpengaruh nyata terhadap jumlah daun rumput gajah umur 4, 6 dan 8 minggu setelah tanam dan jumlah anakan umur 8 minggu stelah tanam. Pemberian dosis bokashi 30 ton $\mathrm{ha}^{-1}$ memberikan rata-rata pertumbuhan dan produksi tertinggi dibandingkan dosis 10 ton ha ${ }^{-1}$ dan 20 ton ha $^{-1}$ serta perlakuan kontrol. Demikian juga [20] menyimpulkan bahwa pemberian pupuk organik bokashi berpengaruh sangat nyata terhadap jumlah daun semai kemiri.

\section{Panjang Daun}

Panjang daun diukur mulai dari pangkaal helaian daun sampai dengan ujung helaian daun tanpa menyertakaan tangkai daun. Rerata panjang helaian daun bervariasi pada masing-masing unit
Adanya pengaruh nyata perlakuan kompos terhadap jumlah daun bayam cabut disebabkan karena kompos adalah pupuk organik yang mampu meningkatkan ketersediaan unsur hara dalam tamah. [17] melaporkan bahwa pemberian bahan organik dapat meningkatkatkan kandungan hara nitrogen, Phofor dan kalium tanah. Pesrsentase kenaikan ketersediaan hara tersebut tergantung dari jenis bahan organik yang diberikan.

percobaan yang diukur 22 hari setelah tanam. Data hasil pengukuran panjang daun bayam cabut disajikan pada tabel 5 .

Pada tabel 5 dapat dilihat bahwa panjang helaian daun tertinggi adalah $67 \mathrm{~mm}$ ditemukan pada perlakuan $1,5 \mathrm{~kg}$ kompos pada 28 hari sebelum tanam. Panjang helaian daun bayam cabut terendah adalah $57 \mathrm{~mm}$ terdapat pada kontrol perlakuan. Adanya perbedaan panjang daun bayam cabut disebabkan karena kompos yang diberikan pada lahan pertanian dapat memperbaiki sifat fisika dan kimia tanah. Selain itu kompos yang diberikan dapat mengalami peruraian menjadi berbagai macam unsur hara yang dibutuhkan untuk mendukung perttumbuhan tanaman bayam cabut. Selanjutnya hasil analisis sidik ragam pengaruh dosis dan waktu pemberian kompos terhadap panjang daun bayam cabut disajikan pada tabel 6 .

Pada tabel 6 dapat dilihat bahwa perbedaan dosis kompos berpengaruh nyata terhadap panjang helaian daun bayam cabut. Ada pengaruh signifikan waktu pemberian kompos terhadap panjang helaian daun bayam cabut. Interaksi antara dosis dan waktu pemberian 
kompos tidak berpengaruh nyata terhadap panjang helaian daun bayam cabut. Aplikasi pupuk organik dapat mempengaruhi sifat kimia tanaah dengan menciptakan keseimbngan hara dalam tanah [21].

Tabel 5. Rerata panjang daun bayam cabut akibat perbedaan dosis dan waktu pemberian kompos

\begin{tabular}{cccc}
\hline Perlakuan & $\begin{array}{c}\text { Panjang Daun } \\
(\mathrm{mm})\end{array}$ & Perlakuan & $\begin{array}{c}\text { Panjang Daun } \\
(\mathrm{mm})\end{array}$ \\
\hline $\mathrm{W}_{1} \mathrm{~K}_{0}$ & 57 & $\mathrm{~W}_{3} \mathrm{~K}_{0}$ & 60 \\
$\mathrm{~W}_{1} \mathrm{~K}_{1}$ & 60 & $\mathrm{~W}_{3} \mathrm{~K}_{1}$ & 62 \\
$\mathrm{~W}_{1} \mathrm{~K}_{2}$ & 60 & $\mathrm{~W}_{3} \mathrm{~K}_{2}$ & 63 \\
$\mathrm{~W}_{1} \mathrm{~K}_{3}$ & 59 & $\mathrm{~W}_{3} \mathrm{~K}_{3}$ & 62 \\
$\mathrm{~W}_{1} \mathrm{~K}_{4}$ & 61 & $\mathrm{~W}_{3} \mathrm{~K}_{4}$ & 63 \\
$\mathrm{~W}_{2} \mathrm{~K}_{0}$ & 58 & $\mathrm{~W}_{4} \mathrm{~K}_{0}$ & 60 \\
$\mathrm{~W}_{2} \mathrm{~K}_{1}$ & 61 & $\mathrm{~W}_{4} \mathrm{~K}_{1}$ & 63 \\
$\mathrm{~W}_{2} \mathrm{~K}_{2}$ & 61 & $\mathrm{~W}_{4} \mathrm{~K}_{2}$ & 63 \\
$\mathrm{~W}_{2} \mathrm{~K}_{3}$ & 62 & $\mathrm{~W}_{4} \mathrm{~K}_{3}$ & 67 \\
$\mathrm{~W}_{2} \mathrm{~K}_{4}$ & 62 & $\mathrm{~W}_{4} \mathrm{~K}_{4}$ & 64 \\
\hline
\end{tabular}

Tabel 6. Hasil analisis sidik ragam pengaruh dosis dan waktu pemberian kompos terhadap panjang helaian daun bayam cabut

\begin{tabular}{lrrrrr}
\hline \multicolumn{1}{c}{ Sumber Keragaman } & DB & \multicolumn{1}{c}{ JK } & \multicolumn{1}{c}{ KT } & F. Hitung & F. Tabel $(0,05)$ \\
\hline Dosis Kompos (K) & 4 & 124,93 & 31,23 & 7,84 & 2,62 \\
Waktu Perlakuan Kompos (K) & 3 & 151,78 & 50,59 & 12,69 & 2,85 \\
W X K & 12 & 42,8 & 3,57 & 0,89 & 1,99 \\
Galat & 38 & 151,44 & 3,98 & & \\
\hline
\end{tabular}

Tabel 7. Rerata diameter batang bayam cabut akibat perbedaan dosis dan waktu pemberian kompos

\begin{tabular}{cccc}
\hline Perlakuan & $\begin{array}{c}\text { Diameter } \\
\text { Batang }(\mathrm{mm})\end{array}$ & Perlakuan & $\begin{array}{c}\text { Diameter } \\
\text { Batang }(\mathrm{mm})\end{array}$ \\
\hline $\mathrm{W}_{1} \mathrm{~K}_{0}$ & 3 & $\mathrm{~W}_{3} \mathrm{~K}_{0}$ & 4 \\
$\mathrm{~W}_{1} \mathrm{~K}_{1}$ & 4 & $\mathrm{~W}_{3} \mathrm{~K}_{1}$ & 4 \\
$\mathrm{~W}_{1} \mathrm{~K}_{2}$ & 4 & $\mathrm{~W}_{3} \mathrm{~K}_{2}$ & 5 \\
$\mathrm{~W}_{1} \mathrm{~K}_{3}$ & 4 & $\mathrm{~W}_{3} \mathrm{~K}_{3}$ & 5 \\
$\mathrm{~W}_{1} \mathrm{~K}_{4}$ & 4 & $\mathrm{~W}_{3} \mathrm{~K}_{4}$ & 5 \\
$\mathrm{~W}_{2} \mathrm{~K}_{0}$ & 4 & $\mathrm{~W}_{4} \mathrm{~K}_{0}$ & 4 \\
$\mathrm{~W}_{2} \mathrm{~K}_{1}$ & 4 & $\mathrm{~W}_{4} \mathrm{~K}_{1}$ & 5 \\
$\mathrm{~W}_{2} \mathrm{~K}_{2}$ & 4 & $\mathrm{~W}_{4} \mathrm{~K}_{2}$ & 5 \\
$\mathrm{~W}_{2} \mathrm{~K}_{3}$ & 5 & $\mathrm{~W}_{4} \mathrm{~K}_{3}$ & 6 \\
$\mathrm{~W}_{2} \mathrm{~K}_{4}$ & 4 & $\mathrm{~W}_{4} \mathrm{~K}_{4}$ & 5 \\
\hline
\end{tabular}

Pada tabel 7 dapat dilihat bahwa diameter batang bayaam cabut tertinggi adalah $6 \mathrm{~mm}$ terdapat pada

Tabel 8. Hasil analisis sidik ragam pengaruh dosis dan waktu Pemberian kompos terhadap diameter batang bayam cabut

\begin{tabular}{lrrrrr}
\hline \multicolumn{1}{c}{ Sumber Keragaman } & DB & \multicolumn{1}{c}{ JK } & KT & F. Hitung & F. Tabel $(0,05)$ \\
\hline Dosis Kompos (K) & 4 & 8,23 & 2,05 & 8,47 & 2,62 \\
Waktu Perlakuan (W) & 3 & 9,33 & 3,11 & 12,80 & 2,85 \\
W X K & 12 & 1,5 & 0,13 & 0,51 & 1,99 \\
Galat & 38 & 9,23 & 0,24 & & \\
\hline
\end{tabular}

Adanya pengaruh nyata perlakuan pupuk organik terhadap panjang daun tanaman juga ditemukan pada tanaman kacang panjang.
Perbedaan dosis pupuk organik bokashi berpengaruh nyata terhadap panjang daun kacang panjang. Hasil pengukuran panjang daun kacang panjang 
tertinggi adalah $114 \mathrm{~mm}$ terdapat pada perlakuan 1,2 $\mathrm{kg}$ bokashi per $1 \mathrm{~m}^{2}$ lahan pertanian. Panjang daun kacang panjang terendah adalah $95 \mathrm{~mm}$ terdapat pada perlakuan kontrol [22]. Selanjutnya penelitian pada kangkung darat disimpulkan bahwa aplikasi pupuk organik bokashi berpengaruh nyata terhadap panjang helaian daun kangkung darat. Dosis optimum pupuk orgsnik bokashi untuk tanaman kangkung darat adalah 1,2 $\mathrm{kg}$ per $8 \mathrm{~kg}$ tanah [23].

\section{Diameter Batang}

Rerata diameter batang bayam cabut bervariasi pada masing-masing dosis kompos yang diberikan. Data rerata diameter bayam cabut yang diukur pada umur 22 hari setelah tanam disajikan pada tabel 7.

perlakuan $\mathrm{W}_{4} \mathrm{~K}_{3}$, yaitu perlakuan $1,5 \mathrm{~kg}$ kompos 28 hari sebelum tanam. Selanjutnya rerata diameter batang bayam cabut terendah adalah $3 \mathrm{~mm}$, ditemukan pada kontrol perlakuan. Hasil analisis sidik ragam pengaruh dosis dan waktu aplikasi kompos terhadap diameter batang bayam cabut disajikan pada tabel 8 .

Pada tabel 8 dapat dilihat bahwa perbedaan dosis kompos berpengaruh nyata terhadap diameter batang bayam cabut. Perbedaan waktu pemberian kompos berpengaruh nyata terhadap diameter batang bayam cabut. Interaksi dosis dan waktu pemberian kompos tidak berpengaruh nyata terhadap diameter batang bayam cabut. Adanya pengaruh nyata dosis pupuk organik terhadap diameter batang tanaman juga ditemukan pada berbagai hasil penelitian. Pertumbuhan jagung manis memiliki respon yang positif terhadap perlakuan pupuk organik, perlakuan pupuk organik dapat meningkatkan tinggi batang, panjang daun, jumlah daun dan diameter batang jagung manis. Dosis optimum pupuk organik untuk pertumbuhan jagung manis adalah $1,5 \mathrm{~kg}$ per $1 \mathrm{~m}^{2}$ lahan pertanian [24]. Perlakuan pupuk organik bokashi berpengaruh nyata terhadap diameter bayam cabut. Dosis pupuk organik bokashi terbaik untuk pertumbuhan bayam cabut adalah $1,6 \mathrm{~kg}$ per $10 \mathrm{~kg}$ tanah [25].

\section{KESIMPULAN}

Berdasarkan hasil analisis data dan pembahasan dalam penelitian ini dapat disimpulkan: (1) perbedaan dosis kompos berpengaruh nyata terhadap tinggi batang, jumlah helaian daun, panjang helaian daun dan diameter batang bayam cabut, (2) perbedaan waktu pemberian kompos berpengaruh nyata terhadap tinggi batang, jumlah helaian daun, panjang helaian daun, lebar helaian daun dan diameter batang bayam cabut, (3) interaksi antara dosis dan waktu pemberian kompos tidak berpengaruh nyata terhadap tinggi batang, jumlah helaian daun, panjang helaian daun, lebar helaian daun dan diameter batang bayam cabut, (4) dosis optimum kompos yang perlu diberikan pada lahan pertanian agar bayam cabut dapat tumbuh optimal adalh $1,5 \mathrm{~kg}$ per $1 \mathrm{~m}^{2}$ lahan pertanian, (5) pemberian kompos 28 hari sebelum tanam memberikan hasil pertumbuhan bayam cabut yang lebih baik dibandingkan dengan pemberian kompos 7, 14 dan 21 hari sebelum tanam.

\section{DAFTAR PUSTAKA}

[1] Rizki, F. (2013). The Miracle of Vegetables. PT Agro Media Pustaka. Jakarta.

[2] Musnamar, E.I. (2003). Pupuk Organik Padat. Penebar Swadaya. Jakarta.

[3] Indrayati, L. (2005). Pengolahan Jerami Padi pada Pertanaman Padi Lahan Pasang Surut Sulfat Masam. Abstrak Hasil Penelitian Pertanian Indonesia Pusat Perpustakaan dan Penyebaran Hasil Penelitian Indonesia. Vol. XII No.2. Bogor.

[4] Raksun, A. Mahrus dan Mertha, I.G. (2021). Effect of Urea and Cow Fecal Commpost on Growth and Yield of Green Eggplat (Solanum melongena, L.). Jurnal Penelitian Pendidikan IPA. 7 (1): $54-59$.

[5] Maruli, Ernita dan Gultom, H. (2012). Pengaruh Pemberian NPK Grower dan Kompos terhadap Pertumbuhan dan Produksi Tanaman Cabai Rawit (Capsicum frustencen L.). Dinamika Pertanian. 27 (3): 149 - 155

[6] Syafriliandi, Murniati dan Idwar. (2016). Pengaruh Jenis Kompos terhadap Pertumbuhan dan Produksi Tanaman Jagung Manis. Jom Faperta. 3 (2) : 1 - 9

[7] Raksun, A., Mahrus, M., \& Mertha, I. G. (2020). Pengaruh Jenis Mulsa Dan Dosis Kompos Terhadap Hasil Panen Cabai Rawit (Capsicum frutescens L.). Jurnal Pijar Mipa, 15(1), 65-68.

[8] Gomez K.A. dan A.A. Gomez. (1991). Prosedur Statistik Untuk penelitian Pertanian Edisi Kedua Penerjemah: Endang Syamsudin dan Justika S. Baharsyah. UI Press. Jakarta.

[9] Teutenburg, H. and Shalabh. (2009). Statistical Analysis of Designed Experiment. Third Edition. Springer. New York

[10] Lawenga, F.F., Hasanah,U. dan Widjajanto, D. (2015). Pengaruh Pemberian Pupuk Organik terhadap Sifat Fisika Tanah dan Hasil Tanaman Tomat (Lycopersicum esculentum Mill) di Desa Bolupountu Kecamatan sigi Biromaru Kabupaten Sigi. Agrotekbis. 3(5): 564570

[11] Hasibuan, A.S.Z. (2015). Pemanfaatan Bahan Organik dalam Perbaikan Beberapa Sifat Fisik Tanah Pasir Pantai Selatan Kulon Progo. Planta Tropika. 3 (1): 31 - 40.

[12] Raksun, A., Japa, L. dan Mertha, I.G. (2018). Pengaruh Kompos Kotoran Kuda Terhadap 
Pertumbuhan Kacang Panjang. Biologi Tropis. 18 (2): $170-173$

[13] Raksun, A., Ilhamdi, M.L., Merta, W.I. dan Mertha, I.G. (2020). Vegetative Growth of Fakcoy Due to Different Dose of Bokashi and NPK Fertilizer. Biologi Tropis. 20 (3): 452 459

[14] Andri, R,K. dan Wawan. (2017). Pengaruh Pemberian Beberapa Dosis Pupuk Kompos (Greenbotane) terhadap Pertumbuhan Bibit Kelapa Sawit (Elaeis quteneensis Jacq). JOM Faperta. 4(2): $1-13$

[15] Ryan, I. (2010). Respon Tanaman Sawi (Brasica juncea.L.) Akibat Pemberian Pupuk NPK dan Penambahan Bokashi pada Tanah Asal Bumi Wonorejo Nabire. Agroforestri. 5 (4): 310 - 320.

[16] Nurcahya, A.O., Herlina, N. \& Guritno, B. (2017). Pengaruh Macam Pupuk Organik dan Waktu Aplikasi terhadap Pertumbuhan dan Hasil Jagung Manis (Zea mays saccharata Sturt). Produsi Tanaman. 5 (9): 1476 - 1482.

[17] Gusmini, Yulnafatmawita \& A.F. Daulay (2008). Pengaruh Pemberian Beberapa Jenis Bahan Organik terhadap Peningkatan Kandungan Hara N, P dan K Ultisol Kebun Percobaan Paperta Unad Padang. J. Solum. 5 (2): $57-65$.

[18] Imas, S., Damhuri dan Munir, A. (2017). Pengaruh Pemberian Pupuk Kompos terhadap Produktivitas Tanaman Cabai Merah (Capsicum annum, L.). Jampibi. 1 2(1): $57-64$

[19] Kusuma, M.E. (2013). Pengaruh Pemberian Bokashi terhadap Pertumbuhan Vegetatif dan Produksi Rumput Gajah. Ilmu Hewani Tropika. 2(2): $40-45$.

[20] Nismawati, R. Wulandari \& Irmasari (2013.) Pengaruh Pemberian Berbagai Dosis Bokashi terhadap Pertumbuhan Semai Kemiri (Aleurites moluccana L.). Warta Rimba. 1(1): $1-8$.

[21] Nuro, F., Priadi, D. dan Mulyaningsih, E.S. (2016). Efek Pupuk Organik Terhadap Sifat Kimia Tanah. dan Produksi Kangkung Darat (Ipomoea reptans Poir). Proseding Seminar Nasional Hasil-Hasil PPM IPB. Bogor.

[22] Raksun, A. dan Japa, L. (2019). Pengaruh Jenis Mulsa dan Dosis Bokashi terhadap Pertumbuhan Kacang Panjang. Jurnal Penelitian Pendidikan IPA. 5 (1): 34 - 38

[23] Raksun, A., Mahrus dan Mertha, I.G. (2020). Vegetative Growth of Kale Land (Ipomoea reptans poir.) Due to Different doses of NPK and Bokashi Fertilizer. Biologi Tropis. 20 (2): $305-313$
[24] Raksun, A., Ilhamdi, M.L., Merta, W.I. dan Mertha, I.G. (2021). Response of Sweet Corn (Zea mays L. Saccharata) Growth on the Treatment of Organic and NPK Fertilizer. Biologi Tropis. 21 (1): 131 - 139

[25] [Raksun, A., Merta, I. W., Mertha, I. G., \& Ilhamdi, M. L. (2020). Pengaruh Bokashi Terhadap Pertumbuhan Bayam Cabut (Amaranthus tricolor L.). Jurnal Pijar Mipa, 15(4), 398-403. 